
www.globaljournalseries.com, Email: info@globaljournalseries.com

\title{
ESTIMATION OF GROUNDWATER POTENTIAL USING SURFICIAL RESISTIVITY MEASUREMENTS: A CASE STUDY FROM PARTS OF MAKURDI BENUE STATE NIGERIA
}

A. E. ADENIJI, A. AJALA AND J. K. OSHO

(Received 18 April 2017; Revision Accepted 4 July 2017)

\begin{abstract}
A geophysical survey involving vertical electrical sounding (VES) was carried out at Makurdi, Benue State Capital which is in the North Central of Nigeria using Schlumberger electrode array. The results show that the area is characterized by 4-5 geoelectric subsurface layers. The measured aquifer thickness ranges from 6 to $69 \mathrm{~m}$, with an average value of $36.7 \mathrm{~m}$ and the aquifer resistivity ranges from 7 to $378 \Omega \mathrm{m}$ with an average of $133.8 \Omega \mathrm{m}$. The aquifer thickness and aquifer resistivity were used to compute the values of the hydraulic conductivity and transmissivity. The aquifer thickness and aquifer resistivity along side with the estimated hydraulic conductivity and Transmissivity were used as indices for evaluation of groundwater potentials. The groundwater productivity potential in the area has been classified into two zones namely; high and intermediate. This study has revealed that no single index determines the groundwater productivity potential but a combination of two or more factors.
\end{abstract}

KEYWORDS: Vertical electrical sounding, groundwater potentials, aquifer resistivity, hydraulic conductivity transmissivity and Makurdi.

\section{INTRODUCTION}

Surface water was the major source of drinkable water since the beginning of mankind or since creation and because of population growth and economic development, surface water in many parts of the world are pushed to their natural limits. Unfortunately, surface water reservoirs which are historically safer and cheaper than groundwater as major potable water resources, have not been properly recharged and maintained to meet the population's need. Hence, the search for groundwater which is strategically valuable because of its high quality and availability as it represents about $97 \%$ of the planet's fresh water (Singh et al., 2006).

Electrical resistivity survey, a geophysical survey technique has proved to be an effective and a reliable tool in locating viable aquifers for continuous and regular water supply (Todd and Mays, 2005). This method has the advantage of non-destructive effect on the environment, cost effective, rapid and quick survey time and less ambiguity interpretations of results when compared to other geophysical survey methods (Todd, 1980).

Correlations between hydraulic and geoelectric parameters have been studied by many authors (Kelly, 1977; Onuoha and Mbazi, 1988; Niwas and Singhal, 1981). These correlations are important because empirical/semi-empirical relations derived from such relationships could be used to extrapolate aquifer parameters using surface resistivity measurements. Unfortunately, the conventional methods for the determination of hydraulic parameters such as pumping tests, permeameter measurements and grain size analysis are invasive, relatively expensive and either integrate over a largest volume of data or provide information only to a small section of the aquifer in the vicinity of the borehole (Mendosa et al.,2003 and Niwas et al.,2011). For these reasons, empirical/semi-empirical relations of estimating the spatial distribution of aquifer parameters such as hydraulic conductivity, transmissivity and aquifer depth are necessary.

\section{DESCRIPTION AND GEOLOGY OF THE AREA}

Makurdi, the Benue State Capital in the North Central of Nigeria is located between latitudes $7^{\circ} 68^{\prime} \mathrm{N}$ and $7^{\circ} 79^{\prime} \mathrm{N}$ and longitudes $8^{\circ} 49^{\prime} \mathrm{E}$ and $8^{\circ} 62^{\prime} \mathrm{E}$ (Figure 1), and covers an approximate area of about 520 square kilometres. The study area is situated in the Guinea Savanah vegetation zone. Annual rainfall in Makurdi town is consistently high, with an average annual total of approximately $1173 \mathrm{~mm}$ (Abah, 2012) which ranges from 775 to $1792 \mathrm{~mm}$. Temperature is generally high in this area. The rainy season lasts from April to October, with 5 months of dry season (November to March). In January, the lowest temperatures of about $26^{\circ} \mathrm{C}$ are usually recorded while the highest of about $32^{\circ} \mathrm{C}$ are recorded in March / April.

A. E. Adeniji, Department of Physical Sciences, Bells University of Technology, Ota, Nigeria.

A. Ajala, Department of Physics and Astronomy, University of Nigeria, Nsukka, Nigeria.

J. K. Osho, Department of Radiation Biology, Radiotherapy, Radio diagnosis and Radiography, University of Lagos, Akoka, Lagos State, Nigeria. 


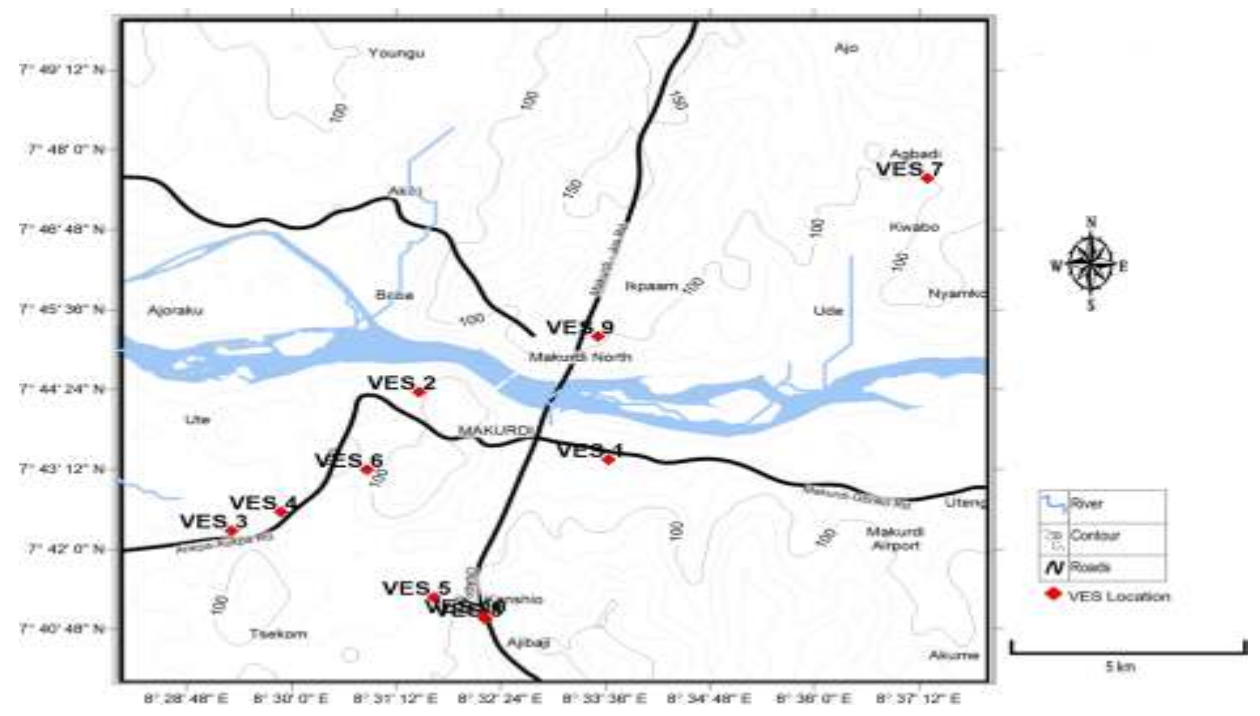

Figure 1: Topographic Map of the study area showing the location of VES locations

The study area is underlain by the Makurdi Formation (Figure 2), which comprises of the lower Makurdi Sandstone: the upper Makurdi Sandstone and the Wadata limestone (Nwajide, 1982). The lower Makurdi Sandstone, which could be found around the Makurdi Airport, consists of sandstones and mudrocks. They are micaceous throughout with mudrocks predominating. The upper Makurdi sandstone is similar to the lower Sandstone but with mudsrocks being relatively less common, as found around the North Bank area of Makurdi. Sandstones and shales outcrop prominently and the sandstone range from very fine to medium in grain size. In this zone, there are shale units of mainly fissile siltstone, usually brownish grey in colour and often abundantly micaceous. Wadata limestone also consists of several limestone occurrences; most outcrops are shelly limestone often closely associated with mudrocks which is the most extensive member of the Makurdi Formation (Nwajide, 1982). The Sandstones in this zone are generally fine to medium grained, moderately sorted, micaceous and feldsphatic. In some parts, they are calcareous, micaceous and shelly. Various types of cement like iron oxides, silica, carbonates and clay were shown to be present in the Makurdi Sandstone, thus making groundwater flow less effective.

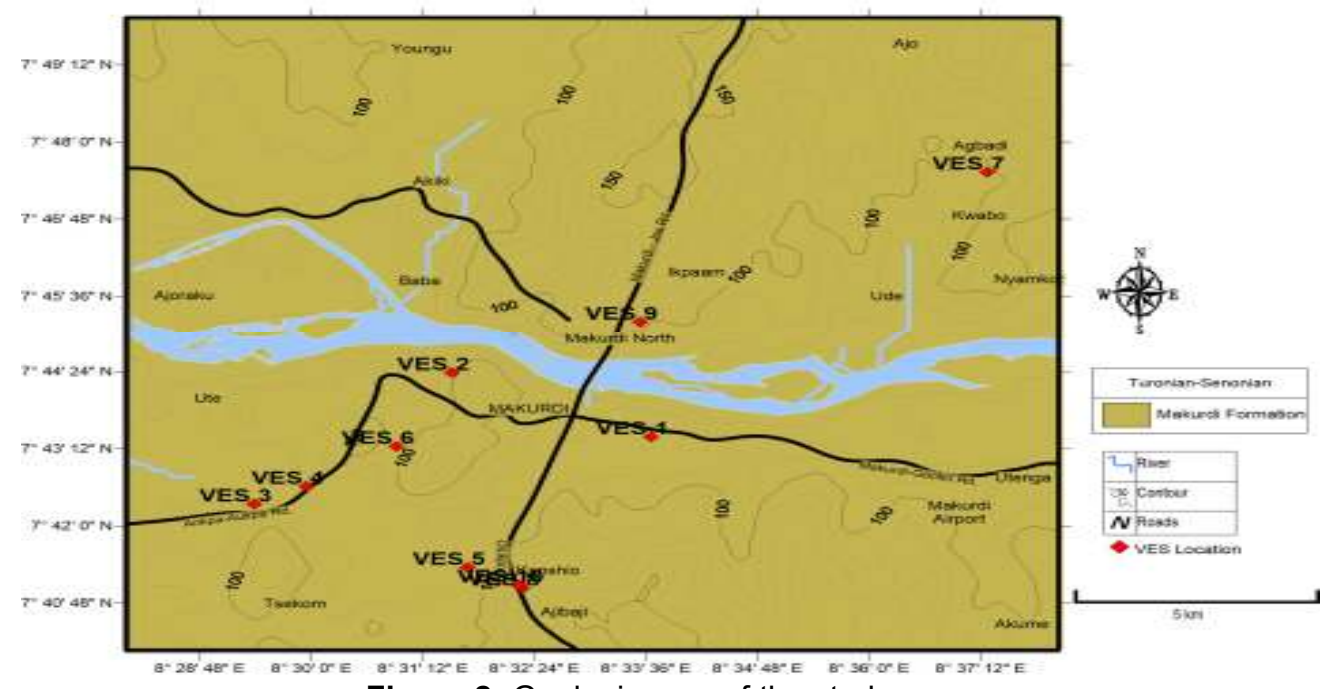

Figure 2: Geologic map of the study area.

\section{Data Acquisition and Method}

Ten (10) vertical electrical sounding (VES) points were carried out in different locations within the study area using PZ-02 resistivity meter. The Arrangement of the electrode configuration was Schlumberger with
Maximum half current electrode spacing $(A B / 2)$ of $100.0 \mathrm{~m}$ and potential electrode spacing (MN/2) of $15.0 \mathrm{~m}$. The apparent resistivity was computed using equation (1); 
$\rho_{a}=\pi\left(\frac{a^{2}}{b}-\frac{b}{4}\right) \frac{\Delta V}{I}$

Where $\rho_{a}$ is the apparent resistivity, $\pi$ is $\frac{22}{7}$, $G=\pi\left(\frac{a^{2}}{b}-\frac{b}{4}\right)$ is geometrical factor, and $\frac{\Delta V}{I}=R$, is the resistance.

The apparent resistivity values obtained from equation (1) were plotted on bi-log graph against the half current electrode separation spacing. From these plots, qualitative deductions, such as the resistivity of the first or top layer, the depth of each layer, and the curve signatures or types were made. The initial quantitative interpretations were made using partial curve matching technique, in which the field curves produced or generated were matched segment by segment with the appropriate master curves and auxiliary curves. The resistivities and thicknesses of the various layers were improved upon by employing an automatic iterative computer program following the main ideas of Zohdy and Martin (1993). The WINRESIST computer software was employed for carrying out the iteration and inversion processes.

The hydraulic conductivity was estimated using the equation as given by Heigold et al. (1979):

$$
K=386.40 R_{r w}{ }^{-0.93283}
$$

Where, $K$ is the hydraulic conductivity and $R_{r w}$ is the aquifer resistivity.

The transmissivity values were calculated using (Todd, 1980):
$T=K h$

Where, $\mathrm{T}$ is transmissivity, $\mathrm{K}$ is hydraulic conductivity and $\mathrm{h}$ is aquifer thickness. This provides a general idea of the water producing capabilities of aquifer from surficial electrical methods.

The total longitudinal conductance $S_{T}$ of the overburden unit at each vertical electrical sounding station was obtained from the mathematical relation (Zohdy et al., 1974):

$S_{T}=\sum_{i=1}^{n} \frac{h_{i}}{\rho_{i}}$

where $S_{T}=$ total longitudinal conductance of the overburden, $\rho_{i}=$ layer resistivity, $h_{i}=$ layer thickness, and $n=$ number of layers and were used to characterize the aquifer protective capacity of the area.

The longitudinal conductance (S) was calculated thus:

$$
S=\frac{h}{\rho}
$$

Where, $\mathrm{h}$ is layer thickness of the aquifer and $\rho$ is layer resistivity of the aquifer.

\section{RESULT AND DISCUSSION}

The summary of the interpreted electrical resistivity survey is presented in Table 1. The VES analysis reveals that the area is characterized by $4-$ to 5 geoelectric subsurface layers with 4 - layer type occurring more. 
Table 1: Summary of the VES analysis.

\begin{tabular}{|c|c|c|c|c|c|c|c|c|c|c|}
\hline $\begin{array}{l}\text { VES } \\
\text { Station }\end{array}$ & Location Name & $\begin{array}{l}\text { Aquifer } \\
\text { Resistivity }\end{array}$ & $\begin{array}{l}\text { Aquifer } \\
\text { Thickness }\end{array}$ & $\begin{array}{l}\text { Longitudinal } \\
\text { Conductance }\end{array}$ & $\begin{array}{l}\text { Hydraulic } \\
\text { Conductance }\end{array}$ & Transmissivity & Latitude & Longitude & $\begin{array}{l}\text { Curve } \\
\text { Type }\end{array}$ & $\begin{array}{l}\text { Groundwater } \\
\text { Potential }\end{array}$ \\
\hline 1 & Gboko Road, MKD & 111 & 32 & 0.28828 & 4.78 & 152.96 & 7.72241 & 8.56058 & $\mathrm{HK}$ & High \\
\hline 2 & Kwararafa, MKD & 256 & 29 & 0.11328 & 2.19 & 63.51 & 7.73935 & 8.52446 & QHA & Intermediate \\
\hline 3 & Industrial Estate, MKD & 176 & 69 & 0.39205 & 3.11 & 214.59 & 7.70466 & 8.48856 & AK & High \\
\hline 4 & $\begin{array}{l}\text { Fed Low Cost Nika } \\
\text { RD, MKD }\end{array}$ & 79 & 7.0 & 0.08861 & 6.56 & 45.92 & 7.70932 & 8.49805 & $\mathrm{HA}$ & Itermediate \\
\hline 5 & $\begin{array}{l}\text { New Kanshio Layout, } \\
\text { MKD }\end{array}$ & 80 & 78 & 0.78006 & 5.26 & 410.28 & 7.68794 & 8.52730 & QHA & High \\
\hline 6 & $\begin{array}{l}\text { David Mark Bye-Pass, } \\
\text { MKD }\end{array}$ & 98 & 22 & 0.22357 & 5.36 & 117.92 & 7.71989 & 8.51439 & $\mathrm{HKH}$ & High \\
\hline 7 & U.A.M & 75 & 57 & 0.76000 & 6.89 & 372.73 & 7.79285 & 8.62162 & HAA & High \\
\hline 8 & Kanshio MKD & 27 & 6.0 & 0.22222 & 17.86 & 107.16 & 7.68247 & 8.53725 & $\mathrm{HA}$ & High \\
\hline 9 & North Bank MKD & 58 & 40 & 0.68966 & 8.75 & 350 & 7.75326 & 8.55861 & $\mathrm{HK}$ & High \\
\hline \multirow[t]{2}{*}{10} & Kanshio MKD & 378 & 27 & 0.07143 & 1.52 & 41.04 & 7.68336 & 8.53665 & $\mathrm{QH}$ & Intermediate \\
\hline & AVERAGE & 133.8 & (36.7 & 0.36291 & 26.228 & $=189.611$ & & & & \\
\hline
\end{tabular}


The curve types obtained from the study area are $\mathrm{HK}$, QHA, AK, HA, QHK, HAA and QH. The 4 - layer geoelectric section is characterized by $\mathrm{HK}, \mathrm{AK}, \mathrm{HA}$ and
QH. (Figures 3, 5, 6 and 9). The 5- layer geoelectric section is characterized by QHA, QHK, and HAA. (Figures

4 , and



Figure 3: Typical HK curve type.

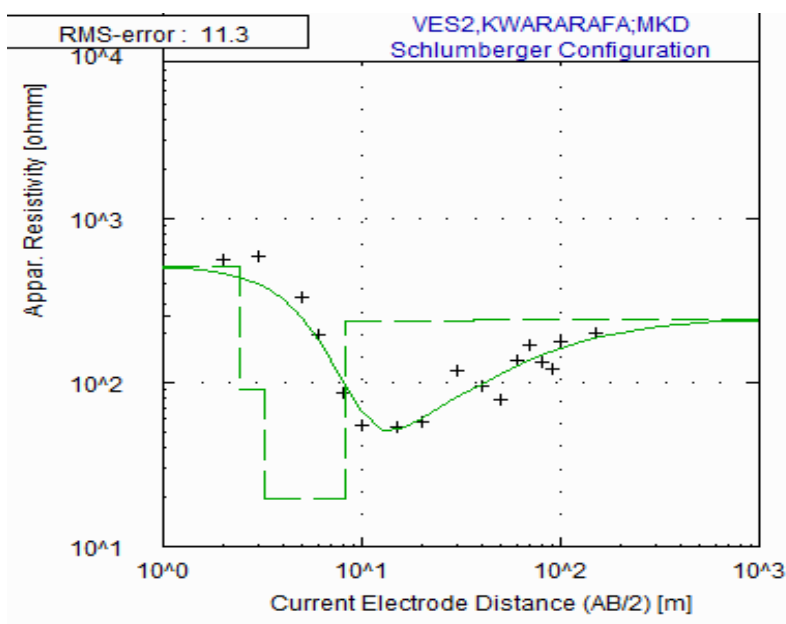

Figure 4: Typical QHA curve type.
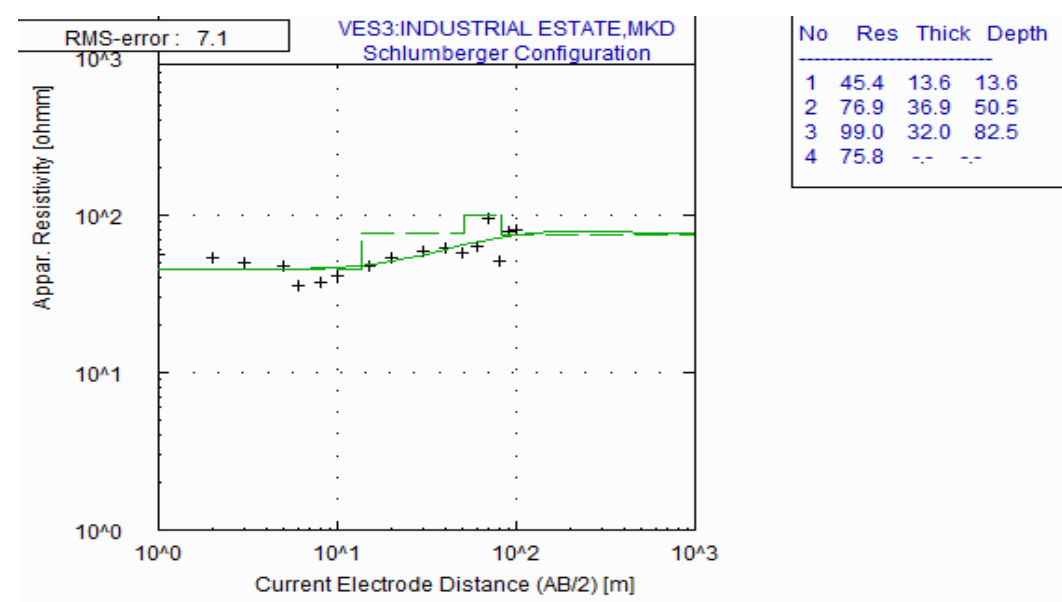

Figure 5: Typical AK curve type.

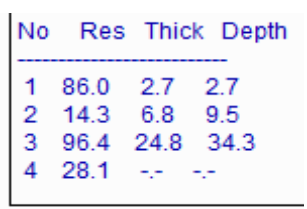

\begin{tabular}{|llll} 
No & Res & Thick & Depth \\
\hline 1 & 508.0 & 2.4 & 2.4 \\
2 & 90.0 & 0.8 & 3.2 \\
3 & 19.8 & 5.0 & 8.2 \\
4 & 236.0 & 28.4 & 36.6 \\
5 & 242.3 &.-- &.-- \\
\hline
\end{tabular}


A. E. ADENIJI, A. AJALA AND J. K. OSHO

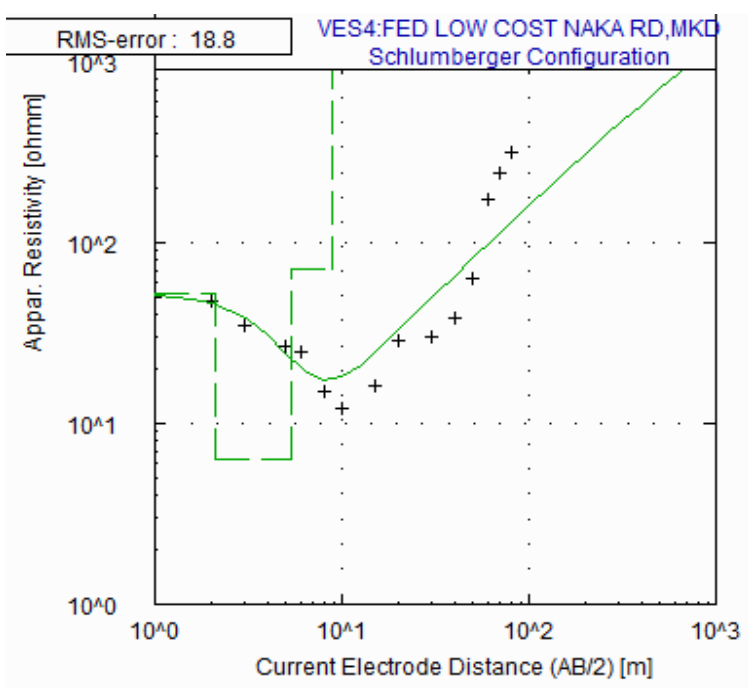

\begin{tabular}{|cccc} 
No & Res & Thick & Depth \\
\hline 1 & 51.9 & 2.1 & 2.1 \\
2 & 6.4 & 3.3 & 5.4 \\
3 & 72.3 & 3.5 & 8.9 \\
4 & 4220.3 &.-- & --
\end{tabular}

Figure 6: Typical HA curve type.
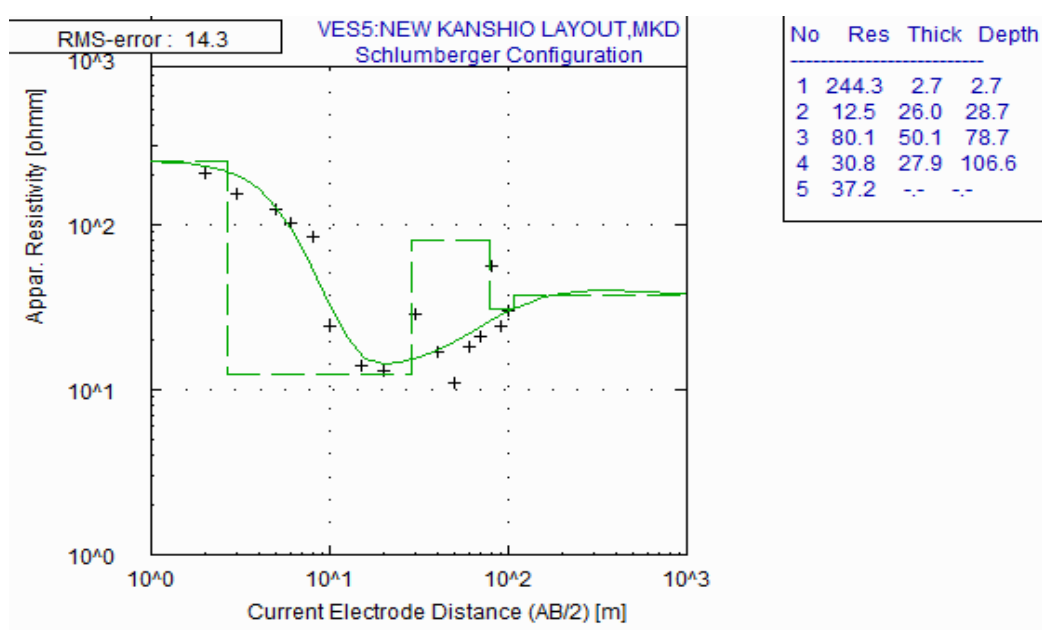

Figure 7: Typical QHK curve type.

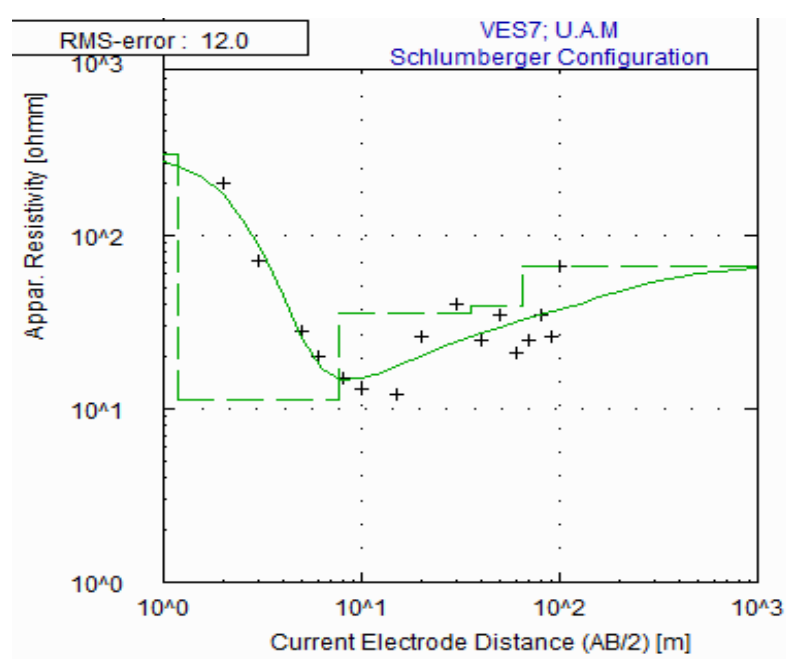

\begin{tabular}{|cccc} 
No & Res & Thick Depth \\
\hline 1 & 293.1 & 1.2 & 1.2 \\
2 & 11.4 & 6.5 & 7.7 \\
3 & 35.3 & 28.2 & 35.8 \\
4 & 39.2 & 29.1 & 64.9 \\
5 & 66.8 &.-- &.-- \\
\hline
\end{tabular}

Figure 8: Typical HAA curve type. 

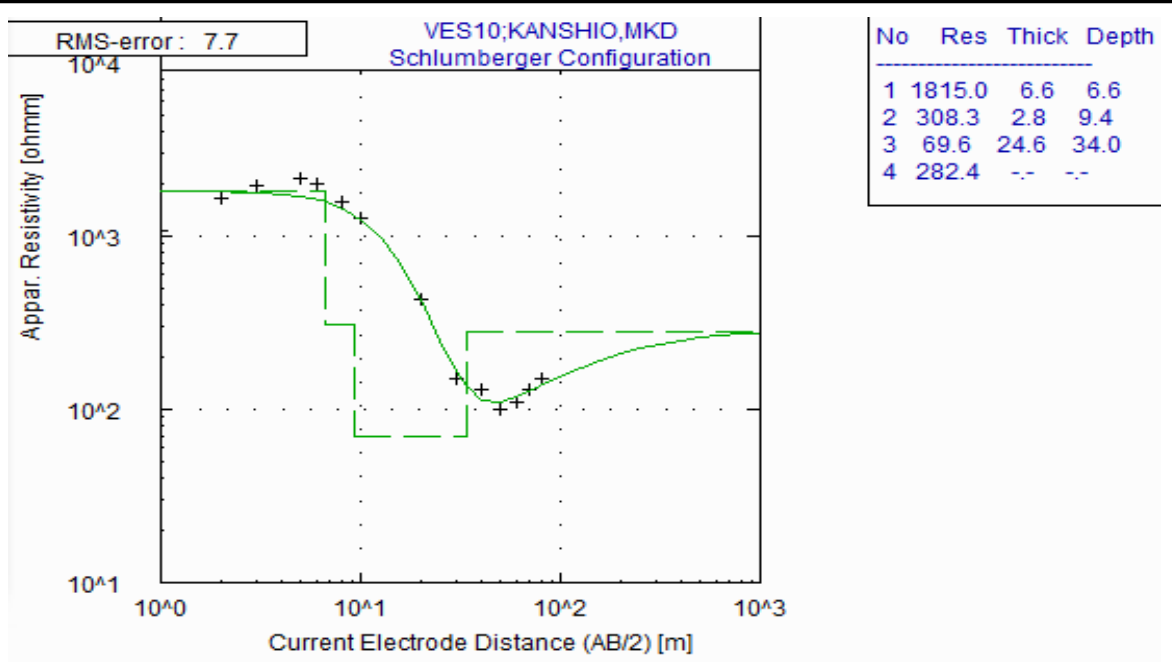

Figure 9: Typical QH curve type.

Table 1 shows the variation of aquifer resistivity and thickness due to lithologic composition, from which the longitudinal conductance, hydraulic conductivity and transmissivity were computed. The aquifer resistivity in the study area ranges from 25 to $378 \Omega m$ with an average of $133.8 \Omega m$ in which the minimum resistivity is observed in point VES 8 , and a maximum resistivity is observed in point VES 10. It also shows the variation of the thickness in the study area in which the minimum value is observed in point VES 4 and a maximum value in point VES 3 with the average of $36.7 \mathrm{~m}$. The groundwater potentials of the area are evaluated based on the following indices; Dar Zarrouk parameters (Aquifer resistivity, Aquifer thickness and longitudinal conductance), hydraulic conductivity and Transmissivity.

Table 1 was used to draw 2D contour maps for all the groundwater potential indices used in the VES analysis. Figure 10 shows the spatial distribution of aquifer resistivity in the study area in which the highest value is observed at VES 10 and the lowest at VES 8. This suggests that zones with low aquifer resistivity values will have high conductive geomaterials, such as poor groundwater quality. Figure 11 shows the spatial distribution of aquifer thickness across the study area. It is observed that the aquifer thickness decreases from the northern part to the southern part of the study area and from the eastern part to the western part of the study area. Figure 12 shows the spatial distribution of Hydraulic conductivity across the study area. Low Hydraulic conductivity is observed in some parts while high hydraulic conductivity is observed in most parts of the study area. Hydraulic conductivity is proportional to effective permeability. Permeability is also fundamental important in aquifer studies and in determining contaminant flow behaviour in the subsurface. It also determines the rate at which water is able to flow into and through porous storage rocks in aquifers (Kelvin Hefferan and John O'Brien, 2010), Areas with high hydraulic conductivity are most likely to have good aquifer recharge quality/capability. Figure 13 shows that high trasmissivity is observed at southern part and some western part of the study area. For characterization of rocks as a water conductivity media, transmissivity is a major property (Fatoba et al, 2014). It can be deduced that groundwater flow potential increases as transmissivity and permeability (Hydraulic conductivity) increases. In order to categorize the groundwater potentials of the area, standards for transmissivity (Krasny,1993) was employed (Table 2).

Table 2: Standards for transmissivity (after Krasny, 1993)

\begin{tabular}{lll}
\hline Transmissivity $\left(\mathrm{m}^{2} /\right.$ day $)$ & Designation & Groundwater supply potentials \\
\hline$\geq 1000$ & Very high & Withdrawal of great regional importance \\
$100-1000$ & High & Withdrawal of lesser regional importance \\
$10-100$ & Intermediate & Withdrawal of local water supply (small community, plants, etc.) \\
110 & Low & Smaller withdrawal for local water supply (private consumption) \\
$0.1-1$ & Very low & Withdrawal for local water supply (private consumption) \\
$<0.1$ & Impermeable & Sources for local water supply are difficult
\end{tabular}


The high groundwater of potential is observed at VES 1 , $3,5,7$ and 9 because of the high values of Hydraulic conductivity, transmissivity and aquifer thickness with low aquifer resistivity. These VES points are zones of high water bearing potential which is most likely to be of great regional importance. The low groundwater potential is observed at VES 2, 4, 6, 8 and 10 due to the high value of aquifer resistivity and low value of the aquifer thickness though some VES stations have high value of Transmissivity and Hydraulic conductivity. These zones are most likely to provide local water supply for private consumption.



Figure 10: Spatial distribution of Aquifer resistivity in the study area.



Figure 11: Spatial distribution of Aquifer thickness in the study area.

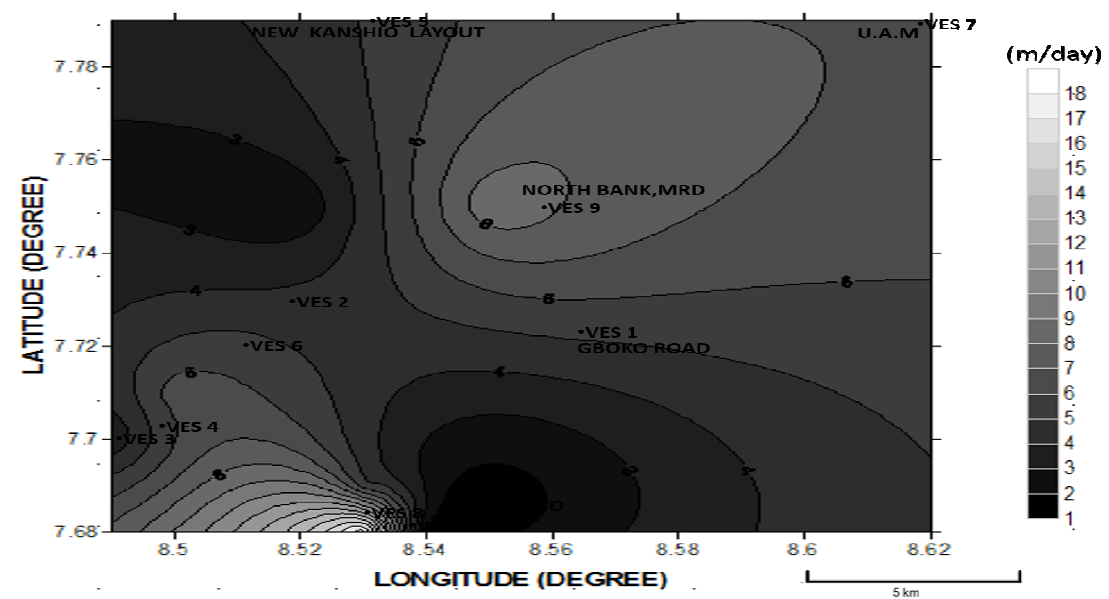

Figure 12: Spatial distribution of Hydraulic conductivity in the study area. 


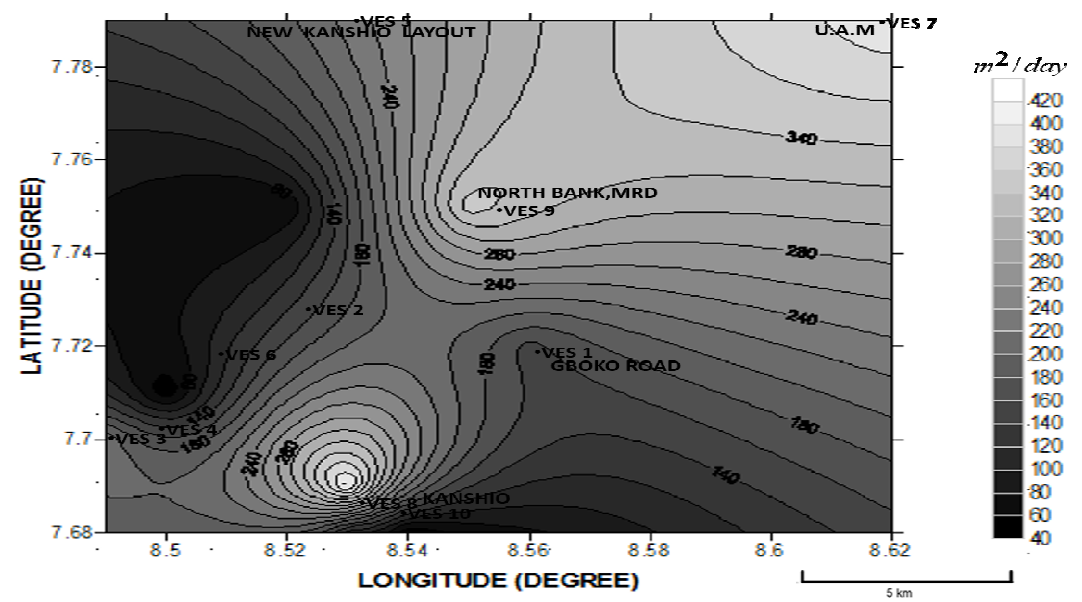

Figure 13: Spatial distribution of Transmissivity in the study area.

\section{CONCLUSION}

The Ten (10) Vertical Electrical Soundings (VES) carried out in Makurdi, Benue State has been used to compute the aquifer hydraulic conductivity and the transmissivity of the survey area. A standard transmissivity model was used to categorize the groundwater potentials of the study area. The zone with the lowest hydraulic conductivity $(1.52 \mathrm{~m} /$ day) has the lowest transmissivity $(41.04 \mathrm{~m} /$ day $)$ which gives the lowest groundwater potential. The emperical relationship established between hydraulic conductivity and aquifer resistivity is a good tool for categorizing groundwater potential. Therefore, geoelectrical sounding technique is an inexpensive tool for calculating the hydraulic parameters and categorizing the aquifer potential of the study area.

\section{REFERENCES}

Abah, R. C., 2012. Causes of seasonal flooding in flood plains: a case of Makurdi, Northern Nigeria. Intl. J. Envtal Studies 69, (6): 904-912.

British geological survey, 2001. Research report on geology of Benue state. Keyworth Nottingham.

Fatoba, J.O., Omolayo, S. D and Adigun, E. O., 2014. Using Geoelectric Soundings for Estimation of Hydraulic Characteristics of Aquifers in the Coastal Area of Lagos, South western Nigeria. Int. Letters Natural Sci. 11: 30-39.

Heigold, P. C., Gilkeson, R. H., Cartwright, K and Reed,

P. C., 1979. Aquifer transmissivity from surficial electrical methods. Ground Water 17, (4): 338345.

Krasny, J., 1993. Classification of transmissivity magnitude and variation. Groundwater 31, (2): 230-236.

Kelly, W. E., 1977. Electrical resistivity for estimating permeability. J. Geotech. Eng. Div. 103:1165-1168.
Hefferan, K and O'Brien, J., 2010. Earth Materials. Wiley-Blackwell, United Kingdom.

Mendosa, F. G., Steenhuis, S. T., Todd, W. M and Parlange, J. Y., 2003. Estimating Basin-Wide Hydraulic Parameters of a Semi-Arid and Mountainous Watershed by Recession-Flow Analysis, Journal of Hydrology 279: (1) 57-69.

Niwas, S., Tezkan, B and Israil, M., 2011. Aquifer Hydraulic Conductivity Estimation from Surface Geoelectrical Measurements for Krauthausen Test Site, Germany, Hydrogeology Journal 19 , (2): 307-315.

Niwas, S and Singhal, D. C., 1981. Estimation of aquifer transmissvity from Dar-Zarrouk parameters in a porous media. Journal of Hydrology 50: 393-399.

Nwajide, C. S., 1982. Petrology and Paleography of the Makurdi Formation. Unpublished Ph.D Thesis, Department of Geology, University of Nigeria Nsukka.

Onuoha, K. M and Mbazi, F. C. C., 1988. Aquifer transmissivity from electrical sounding data: the case of Ajali Sandstone aquifers South - west of Enugu, Nigeria, in Ofoegbu, C.O., Ed. Groundwater and mineral resources of Nigeria. Vieweg-Verlag, 17-30.

Singh, K. K. K., Singh, K. A., Singh, K. B and Sinha, A., 2006. 2D resistivity imaging survey for sitting watersupply tube wells in metamorphic terrains: A case study of CMRI campus, Dhanbad, India. The Leading Edge 25:1458.

Todd, K. D and Mays, L. W., 2005. Groundwater Hydrology. $3^{\text {rd }}$ ed. John Wiley and Sons, New York, 636.

Todd, K. D., 1980. Groundwater Hydrology. 2nd ed. John Wiley and Sons, New York, 535. 
Zohdy, A. A. R and Martin, R. J., 1993. A study of sea water intrusion using direct current sounding in the southern part of the Ox ward Plain California; U.S. Geological Survey.

Zohdy, A. A. R., Eaton, G. P and Mabey, D. R., 1974. Application of surface geophysics to groundwater investigations; United State Geophysical Survey, Washington. 